\section{耐震診断結果に基づく北海道の 既存 RC 造建築物の実測コンク リート強度及び地震被害予測}

\title{
ACTUAL CONCRETE STRENGTH AND SEISMIC DAMAGE PREDICTION OF EXISTING REINFORCED CONCRETE BUILDINGS IN HOKKAIDO BASED ON SEISMIC DIAGNOSIS
}

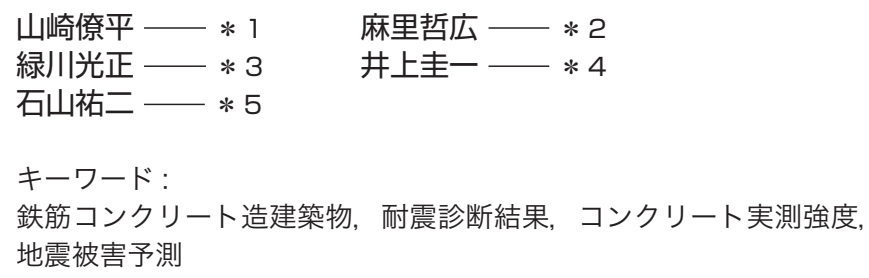

Keywords:

Reinforced concrete building, Seismic diagnosis, Actual concrete strength, Seismic damage prediction

\section{1.はじめに}

1995 年に発生した兵庫県南部地震により多くの建築物に被害が 生じた。被害状況をみると 1981 年に建築基準法施行令が改定される 以前の耐震設計法で設計され、現行の耐震基準を満たさない建築物 の被害が相当顕著であった。このことから、旧基準法令で設計され た一定規模以上の建築物について、耐震診断・耐震改修を義務付け た「建築物の耐震改修の促進に関する法律」が 1995 年 12 月 25 日に 施行され、全国的に公共建築物を中心とした耐震診断及び而震改修 が実施されている。

筆者らはこれまで、北海道内で行われた鉄筋コンクリート造（以 下、 $\mathrm{RC}$ 造）建築物の耐震診断結果を収集するとともに、北海道内の $\mathrm{RC}$ 造建築物の耐震性能等について検討を行ってきた例吂ば1),2)。

本研究では、これまで行われた耐震診断結果を用い、北海道の既 存 $\mathrm{RC}$ 造建築物の耐震性能や地震時にどの程度の被害が生じると推 定されるか、補強により被害率がどの程度軽減されるか、等につい て検討を行う。

また、耐震診断の際に採取したコンクリートコア供試体の圧縮試 験より得られた推定強度と設計基準強度や竣工年との関係、および 実測コンクリート強度が地震被害率にどの程度影響を与えるかにつ いても検討を行う。

\section{RC 造建築物の耐震診断基準の概要}

本研究では、日本建築防災協会の耐震診断基準 ${ }^{3)}$ を基に検討を行 う。耐震診断基準では、構造耐震指標 $I_{S}$ 值と構造耐震判定指標 $I_{S 0}$

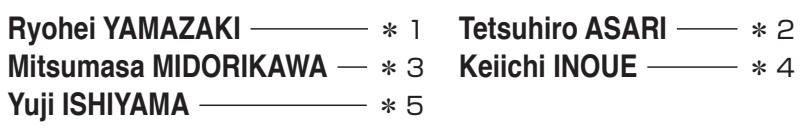

In this paper, we investigate the seismic performance of existing reinforced concrete buildings, the damage prediction and the actual concrete strength based on the seismic diagnosis results from 1996 to 2006 in Hokkaido. The following conclusions are obtained: (1) 79\% of buildings built before 1971 do not satisfy the sesmic capacity index $I s \geqq 0.6$; (2) The average ratio of actual concrete strength by core tests to design basis one is 1.39 ; (3) The seismic retrofit of buildings reduces the predicted seismic damage ratio over moderate damage rank to approximately one fourth as compared to the non-retrofit buildings under the earthquake ground motion level of JMA seismic intensity of 6 .
值を用いる。 $I_{S}$ 值及び $I_{S 0}$ 值は建築物各階の梁間及び桁行方向それ ぞれについて算定され、 $I_{S} \geq I_{S 0}$ ならば「安全」とし、そうでなけ れば構造体の耐震性に「疑問あり」とする。

$I_{S}$ 值判断の目安として、0.4 未満であると大地震時に大破・倒壊 などの被害を受ける可能性が高く、0.6 未満であると大地震時に何 らかの被害を受ける可能性が高いとされている ${ }^{3), 4) 。 ~}$

各指標は次式で表される。

$$
\begin{gathered}
I_{S}=E_{o} \times S_{D} \times T \\
E_{O} \text { : 保有性能指標、 } S_{D} \text { :形状指標、 } T \text { : 経年指標 } \\
I_{S 0}=E_{S} \times Z \times G \times U
\end{gathered}
$$

$E_{S}$ : 耐震判定基本指標、 $Z$ : 地域指標、 $G$ : 地盤指標、 $U$ :用途指標

\section{3. 北海道の $\mathrm{RC}$ 造建築物の耐震診断結果}

\section{(1) 対象建築物}

1996 年 9 月から 2006 年 12 月までに、(社) 北海道建築設計事務所 協会および(財) 北海道建築指導センターの耐震診断委員会において 第 2 次診断が行われた 7 層以下の $\mathrm{RC}$ 造建築物 698 棟を対象とする。 診断結果の内訳を表 1 に、用途別の内訳を表 2 に示す。表 1 では建 設年代を、1971 年の建築基準法改定が行われる以前、1972 年から 1981 年の新耐震設計基準導入まで、それ以後の三期に区分している。

\section{表 1 建設年代別の対象建築物（計 698 棟）}

\begin{tabular}{c|ccccc}
\hline 建設年代 & 棟数 & Is值不足棟数 & 不足棟数割合 & 平均Is値 & 平均 $\mathrm{C}_{T U} \cdot \mathrm{S}_{\mathrm{D}}$ 值 \\
\hline$\sim 1971$ & 206 & 163 & $79.1 \%$ & 0.47 & 0.44 \\
$1972 \sim 1981$ & 469 & 307 & $65.5 \%$ & 0.63 & 0.58 \\
$1982 \sim$ & 23 & 11 & $47.8 \%$ & 0.98 & 0.73 \\
\hline
\end{tabular}

\footnotetext{
北海道大学大学院工学研究科 修士課程 ( ( 060-8628 北海道札幌市北区北 13 条西 8 丁目)

北海道大学大学院工学研究科 助教・博士 (工学)

北海道大学大学院工学研究科 教授・工博

福井大学大学院工学研究科 講師・博士 (工学)

北海道大学 名誉教授・工博
}

\footnotetext{
Graduate Student, Graduate School of Eng., Hokkaido Univ.

Asst. Prof., Graduate School of Eng., Hokkaido Univ., Dr. Eng. Prof., Graduate School of Eng., Hokkaido Univ., Dr. Eng. Lecturer, Graduate School of Eng., Univ. of Fukui, Dr. Eng.

Prof. Emeritus, Hokkaido Univ., Dr. Eng.
} 
表 1 より、1971 年以前に建設された建築物の $79 \%$ 品 $I_{S} \geq I_{S 0}$ を満た しておらず、1971 年以降の建築物についても $I_{S} \geq I_{S 0}$ を満たしてい ないものが多くみられる。

表 2 用途別対象建築物棟数（計 698 棟）

\begin{tabular}{|c|c|c|c|c|c|c|c|}
\hline 用途 & 校舎 & 集合住宅 & 市庁舎 & 病院 & 警察·消防 & 社会福祉施設 & その他 \\
\hline 棟数 & 432 & 37 & 27 & 17 & 55 & 42 & 88 \\
\hline 棟数割合 & $62 \%$ & $5 \%$ & $4 \%$ & $2 \%$ & $8 \%$ & $6 \%$ & $13 \%$ \\
\hline
\end{tabular}

表 2 より、耐震診断が実施された建築物のうち校舎が約 6 割を占 めている。これは、過去の地震において校舎の被害率が高い事、お よび校舎が災害時に地域の防災拠点（主に避難収容施設）となるケ 一スが想定され、地震後も建物本来の機能維持が求められている事 が要因の 1 つと考えられる。

\section{(2) 北海道の RC 造建築物の構造耐震指標 $I_{S}$}

対象とする 698 棟の建築物のうち耐震診断の結果から補強が必要 と判定され、かつ補強計画・耐震改修が行われた 407 棟の桁行・梁 間方向の補強前、補強後の $I_{S}$ 值の分布を図 1 に示す。

なお、ここでは建築物の長辺方向を桁行、短辺方向を梁間とし、 また階、方向に関わらず建築物の $I_{S}$ 値の最小値をその建築物の $I_{S}$ 值としている。

図 1 中に示した曲線は $I_{S}$ 值の分布を頻度分布曲線として一般に 用いられる対数正規分布で近似したものである。対数正規分布は、 次式の確率密度関数 $P_{I S}$ で表される。

$$
P_{I S}=\frac{1}{\sqrt{2 \pi} \cdot \sigma_{y} \cdot x} \exp \left[-\frac{1}{2} \cdot \frac{(y-\bar{y})^{2}}{\sigma_{Y}^{2}}\right]
$$

$x: I s$ 值, $y: \ln (x)$ 值, $\bar{y}: y$ の平均值, $\sigma_{y}: y$ の標準偏差

図 1 から、補強前は大地震動時に大破、倒壊等の被害を受ける危 険性が高いとされる $I_{S}$ 值が 0.4 未満のものが $43 \%$ あ、被害の大 小に関わらず大地震動により損傷を受ける可能性があるとされる $I_{S}$ 值が 0.6 末満のものが $90 \%$ あ。

図 2 に各建築物の梁間方向と桁行方向における補強前の構造耐震 指標 $I_{S}$ の最小值を示す。なお、 $I_{S}$ 值は構造耐震判定指標 $I_{S O}$ で除し て基準化した。図 2 より、梁間方向の $I_{S}$ 值の $38 \%$ 、桁行方向の $I_{S}$ 値 の $90 \%$ が $I_{S O}$ 值を下回っている。

（3）終局限界時の累積強度指標 $C_{T U}$ と形状指標 $S_{D}$

第 2 次診断、第 3 次診断の構造耐震判定指標 $I_{S O}$ のレベルは、勒 性指標值が大きい範囲で、現行の建築基準法令のレベルより低くな る可能性があり、これを避け必要保有水平耐力に対応する構造特性 係数を満足するために構造物の終局限界における累積強度指標 $C_{T U}$ と形状指標 $S_{D}$ による判定が用いられている。

$C_{T U} \cdot S_{D} \geq 0.3 \cdot Z \cdot G \cdot U$ であれば「安全」とし新而震設計法で設計 される建物とほぼ同程度の耐震性能を持つと考え、そうでなければ 構造体の耐震性能が「不足」となる。

$C_{T U} \cdot S_{D}$ は次式で表される。

$$
C_{T U} \cdot S_{D}=(n+1) /(n+i) \times C \times S_{D}
$$

$C_{T U}$ : 終局限界時の累積強度指標、 $C$ : 強度指標、 $S_{D}$ :形状指標 $n$ : 総層数、 $i$ : 検討する層
図 3 に各建築物の補強前の梁間方向と桁行方向における $C_{T U} \cdot S_{D}$ の 最小值を示す。 $C_{T U} \cdot S_{D}$ 值は、安全性判定の指標となる $0.3 \cdot Z \cdot G \cdot U$ で除して基準化した。図 3 より、梁間方向の $C_{T U} \cdot S_{D}$ 值の $9 \%$ 、桁行方向 の $C_{T U} \cdot S_{D}$ 值の $20 \%$ が $0.3 \cdot Z \cdot G \cdot U$ を下回っている。

\section{(4) 見かけの靭性指標 $F^{\prime}$}

見かけの勒性指標 $F^{\prime}$ は、下式によって算定する。

$$
F^{\prime}=\frac{I_{s}}{C_{T U} \cdot S_{D} \cdot T}
$$

見かけの勒性指標 $F^{\prime}$ は建物の真の勒性指標と必ずしも対応して いるものではないが、その建築物の勒性を評価する上の目安となる。

図 4 に、 $C_{T U} \cdot S_{D}$ 值と $F^{\prime}$ の関係を示す。図中の曲線は、 $I_{S}$ 值判断 の目安となる $I_{S}=0.6$ 及び $T=0.97$ （経年指標の平均值）とした時の 見かけの勒性指標 $F^{\prime}$ を表している

図 4 より、補強前はほとんどが曲線よりも下に分布しているが、補強 計画後は $F^{\prime}$ はあまり増加せず、 $C_{T U} \cdot S_{D}$ が増加することによって、 分布が曲線よりも上へ移動している。このことより、耐震補強の際 に強度抵抗型の補強が多いことがわかる。

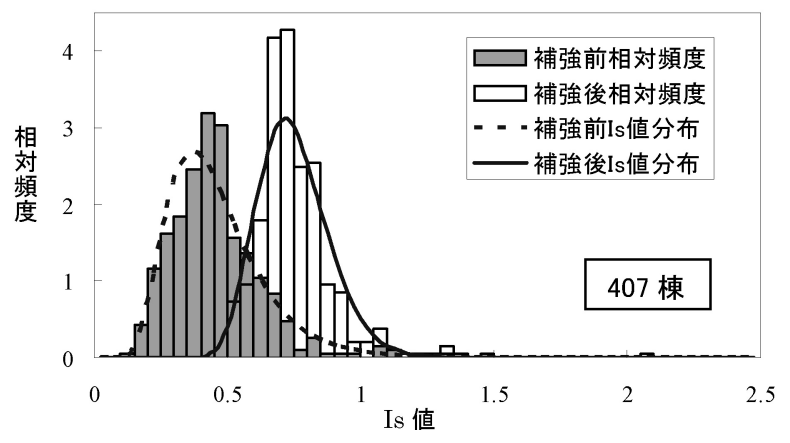

図 1 対象建築物のIs 值分布

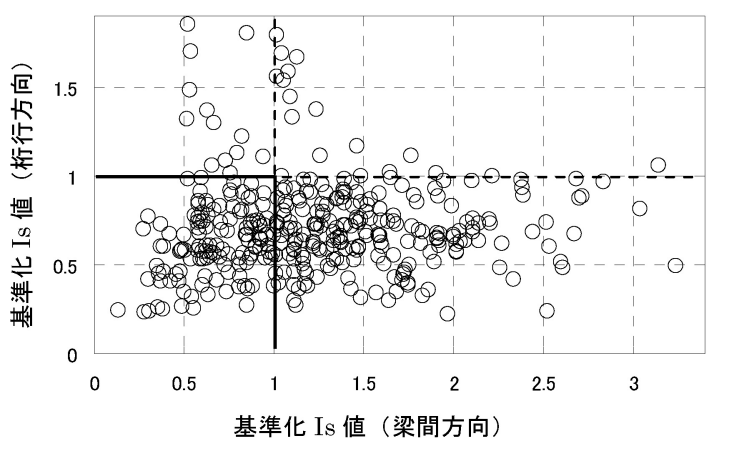

図 2 基準化 Is 值(補強前)

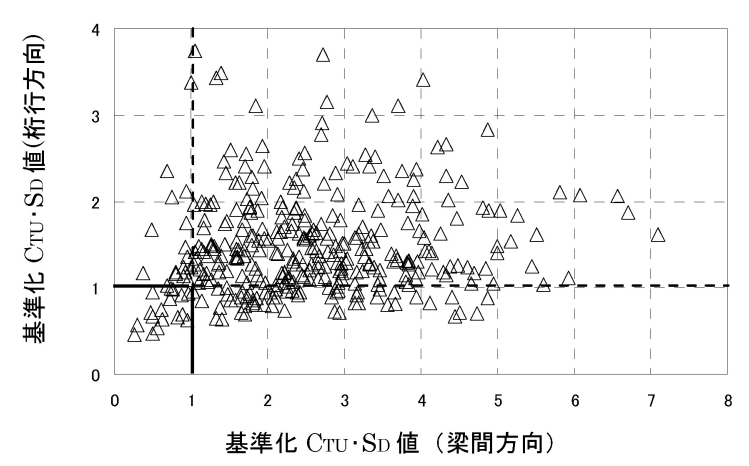

図 3 基準化 $\mathrm{CTU}_{T} \cdot \mathrm{SD}_{\mathrm{D}}$ 值 (補強前) 


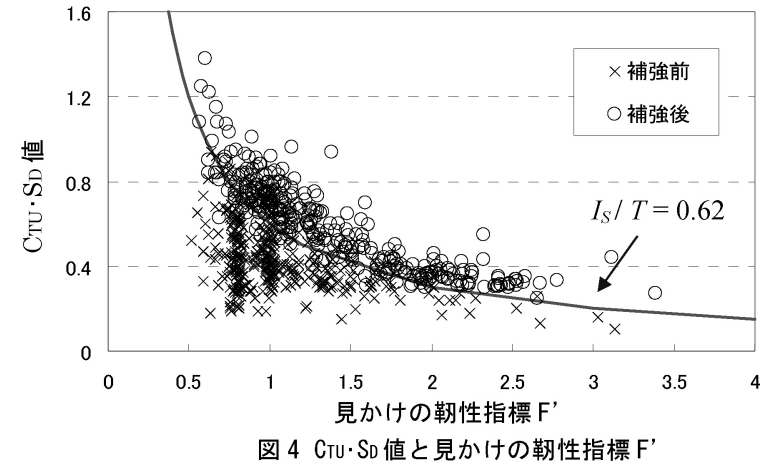

4. 補強前後の耐震診断結果の比較

(1) 耐震補強方法

図 5 は3.(2) で対象とした 407 棟の建築物における補強方法の内 訳を示したものである。建築物 1 棟に対して複数の方法を採用して いる場合もあるため、合計棟数は 407 棟よりも多くなっている。補 強方法としては、耐震壁の増設が最も多く、次に柱とそれに接合さ れている壁との間を構造的に切り離すスリットが採用されている。 スリットが採用されていた建物のうち、約半数の 113 棟は耐震壁の 増設も同時に行われていた。ブレース補強は鉄骨ブレースが、柱補 強では鋼板巻きと炭素繊維シート巻きが多い。

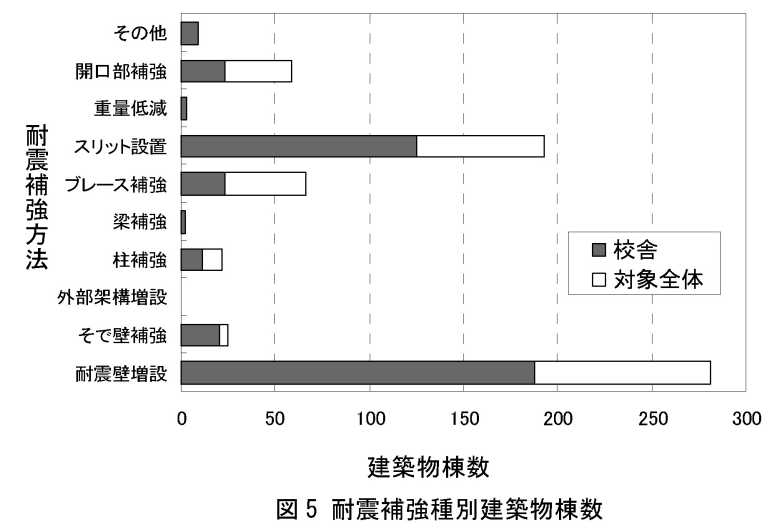

(2) 補強前後の構造耐震指標 $I_{S}$ 之終局限界時の累積強度指標 $C_{T U}$

図 $6(\mathrm{a}),(\mathrm{b})$ に、対象建物の補強前後の最小 $I_{S}$ 值とそれに対応寸る $C_{T U} \cdot S_{D}$ 值の関係を示す。 $I_{S}$ 值を $I_{S 0}$ で、 $C_{T U} \cdot S_{D}$ 值を $0.3 \cdot Z \cdot G \cdot U$ でそれぞれ除して基準化している。ここでは、桁行・梁間方向の $I_{S}$ 值、 $C_{T U} \cdot S_{D}$ 值の最小值を、それぞれその建築物の $I_{S}$ 值、 $C_{T U} \cdot S_{D}$ 值とし た。

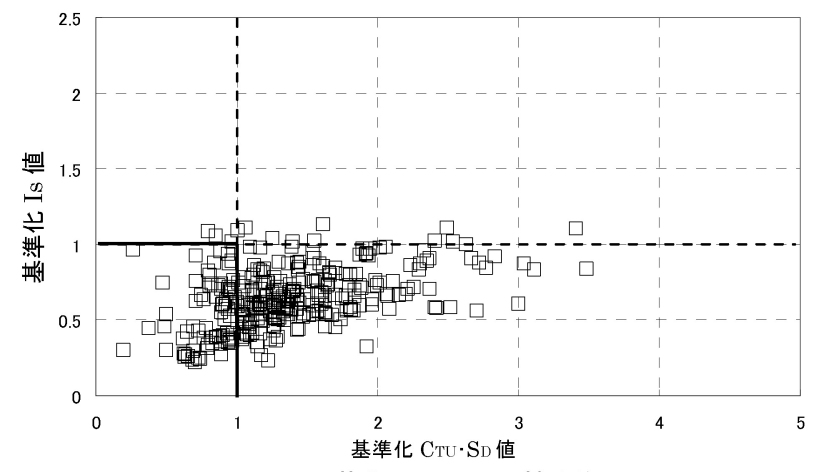

図 6 (a) 基準化 $\mathrm{Is}, \mathrm{C}_{\mathrm{Tu}} \cdot \mathrm{S}_{\mathrm{D}}$ (補強前)

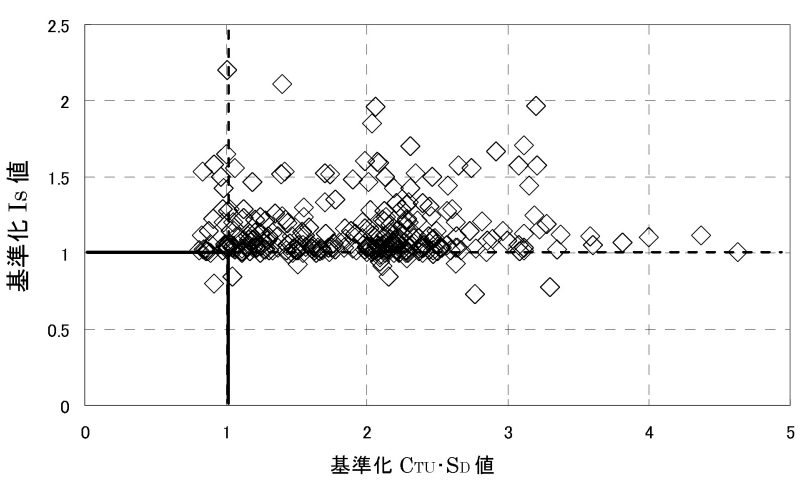

図 6 (b) 基準化 Is, $\mathrm{C}_{\mathrm{Tu}} \cdot \mathrm{S}_{\mathrm{D}}$ (補強後)

図 6 (a)より、補強前には、基準化 $I_{S}$ 値の $96 \%$ 、基準化 $C_{T U} \cdot S_{D}$ 値の 26\%が1を下回っている。図 6 (b)より、補強によってほとんどの建築 物において基準化 $I_{S}$ 値、基隻化 $C_{T U} \cdot S_{D}$ 値ともに 1 を上回るように なっているが、1 を下回るものも、基準化 $I_{S}$ 値、基準化 $C_{T U} \cdot S_{D}$ 値と もに約 10\%存在している。

\section{5. コンクリートコアより得られた実測コンクリート推定強度}

（1）実測コンクリート推定強度

耐震診断が実施される際に、対象となる建築物において各層 1 3 本のコンクリートコアが採取されており、JIS A-1107 に準拠した方法によ りコアによる圧縮強度試験が行われ、コンクリートの圧縮強度が推 定されている。本研究では、耐震診断基準 ${ }^{3)}$ に基づき各階のコアの 平均值 $\left(X_{\text {mean }}\right)$ から標準偏差 $(\sigma)$ の $1 / 2$ を差し引いた值を各階の推定強 度 $\left(\sigma_{B}\right)$ として算定し、それを実測コンクリート推定強度として用いる。

(2) 対象データ

698 棟のうち、コンクリートコアによる圧縮試験が行われた 313 棟の建築物を対象とする。図 7 に対象建築物の竣工年別の棟数を示 す。

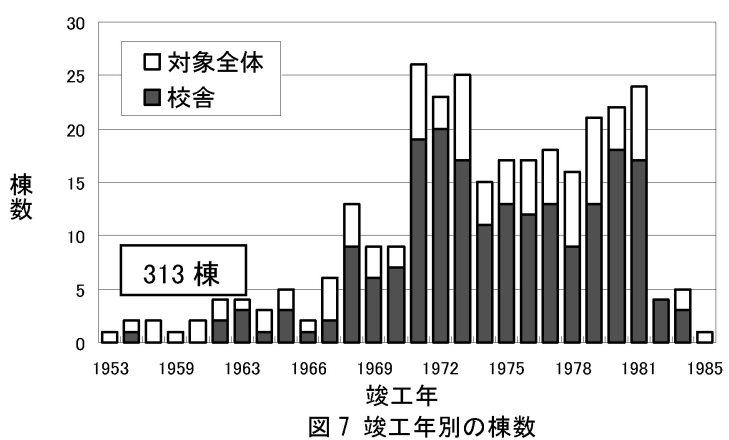

\section{（3）竣工年による圧縮強度の推移}

各建築物毎の実測コンクリート推定強度と竣工年の関係を図 8 に、 実測コンクリート推定強度を設計基準強度で除した圧縮強度比と䇋 工年の関係を図 9 に示す。

図 8 より実測コンクリート推定強度と竣工年との関係は、右上が りの傾向を示しており、設計基準強度の増加に伴って、コンクリー 卜強度が上昇してきている傾向が見られる。文献 5)による関東地方 $\mathrm{A}$ 県の推定強度の回帰直線と今回算出した実測コンクリート推定強 度の回帰直線を比較すると、両者はほぼ合致している。設計基準強 度を下回るものは全体の約 $5 \%$ 存在する。 


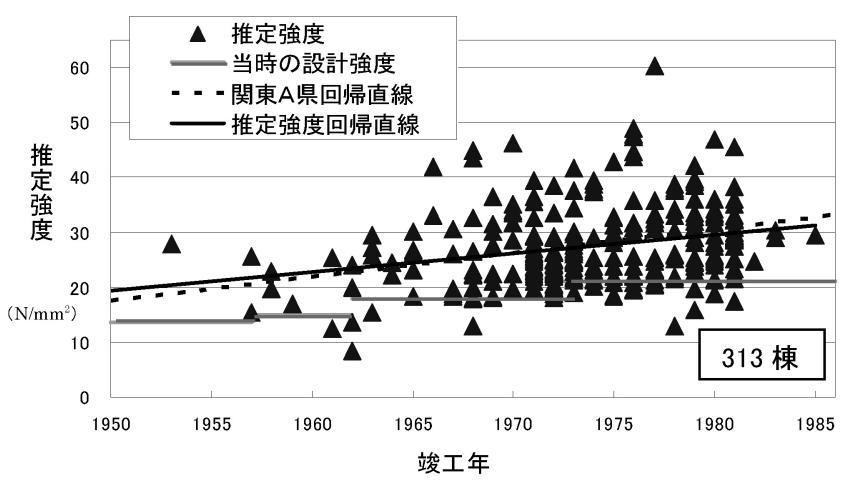

図 8 竣エ年別の実測コンクリート推定強度

図 9 より圧縮強度比の平均は 1.39 であり、これは東北地方におけ る值 $1.28^{6)}$ や関東 $\mathrm{A}$ 県下における值 $1.27^{5)}$ を上回っている。 [平均 值-標準偏差]の值が 1.0 を下回っているものも年代によらずみられ る。

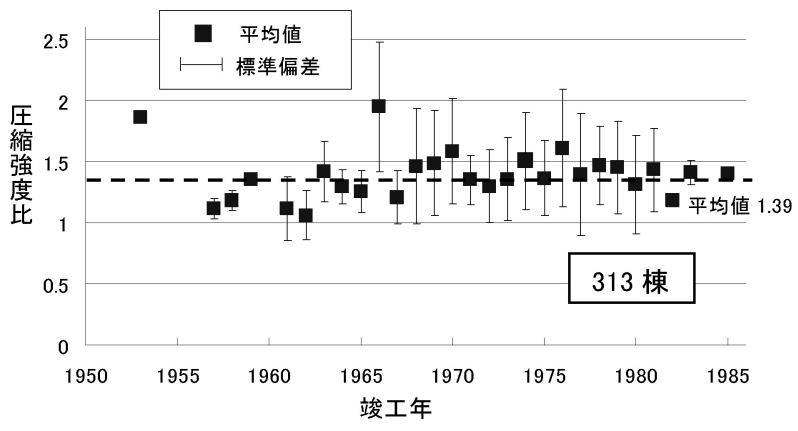

図 9 竣工年別の圧縮強度比の平均値と標準偏差

\section{6. 北海道の $\mathrm{RC}$ 造建築物の地震被害予測}

\section{(1) 予測方法}

中埜、岡田 ${ }^{7)}$ は地震後の $\mathrm{RC}$ 造建築物の被害状況と耐震診断結果を 基に、信頼性理論により被害率を算定し、地震被害予測を行った。 本研究では、この方法に準じて被害率を予測する。

\section{（2）使用データ}

1968 年十勝沖地震レベルおよび 1978 年宮城県沖地震レベルの被 害率の推定にあたっては、文献 7) で算出された被害率 (中破以上の 被害率 $11 \%$ ）を用いる。

1995 年兵庫県南部地震レベルの被害率算定にあたっては、日本建 築学会構造委員会の 1995 年兵庫県南部地震鉄筋コンクリート造建 築物の被害調查報告書 ${ }^{8)}$ による中破以上の被害を受けた 46 棟の建 築物の診断結果の分布（最小 $I_{S}$ 値）と兵庫県南部地震で中破以上の 被害率が $29 \%$ であったことにより求めている ${ }^{9)}$ 。なお、この調查は、 被災した全ての地区で全数調查が行われたわけではなく、全数調查 が行われたのは西宮市、神戸市灘区・東灘区・中央区・兵庫区であ つた。

\section{（3）被害確率分布の算定}

文献 7)によると入力地動のばらつきによる荷重効果 $E_{T}$ 值の分布 を $P_{E T}$ とすると、実被害データを用いて $P_{E T}$ は次式で表される。

$$
\begin{gathered}
P_{E T}=\frac{1}{\sqrt{2 \pi} \cdot \sigma_{x}} \exp \left[-\frac{1}{2} \cdot \frac{(x-\bar{x})^{2}}{\sigma_{x}^{2}}\right] \\
x: \mathrm{E}_{\mathrm{T}} \text { 值, } \bar{x}: x \text { の平均値, } \sigma_{x}: x \text { の標準偏差 }
\end{gathered}
$$

「全建物に対する被害建物数の割合」を「被害率 $V$ 」と定義すると、被 害率 $V$ および被害建築物の $I_{S}$ 值分布 $v(x)$ はそれぞれ次式で表せる。

$$
\begin{gathered}
V=\int_{0}^{\infty} v(x) d x, \quad v(x)=P_{I S} \cdot\left[1-\int_{0}^{x} P_{E T}(r) d r\right] \\
x: I_{S} \text { 值, } \mathrm{r}: E_{T} \text { 值 }
\end{gathered}
$$

$P_{E T}$ は、建築物の位置する地盤により入力地震動が異なるために、 建築物の応答がばらつき、従って建築物が安全であるために必要な $I_{S}$ 值（すなわち $E_{T}$ 值）があるばらつきをもった確率量になること を表した $E_{T}$ 值の確率密度関数である。

また $1-\int_{0}^{\infty} P_{E T}(r) d r$ は $I_{S} \geq x$ の建築物の被害率を、 $E_{T}$ は被害建 築物の $I_{S}$ 値の分布を示寸(図 10 参照)。

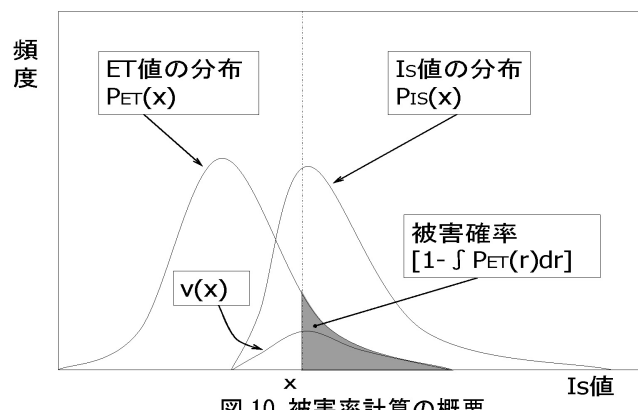

図 10 被害率計算の概要

図 11 (a)に示寸曲線は、文献 7) で求められた 1968 年十勝沖・1978 年宮城沖地震の実被害データに基づく荷重効果 $E_{T}$ 値の分布 $P_{E T}$ で ある。図 11 (b) は、同様の手法を用い、1995 年兵庫県南部地震の実 被害データに基づく $E_{T}$ 值分布と $v(x)$ 分布を求めたものである ${ }^{9)}$ 。

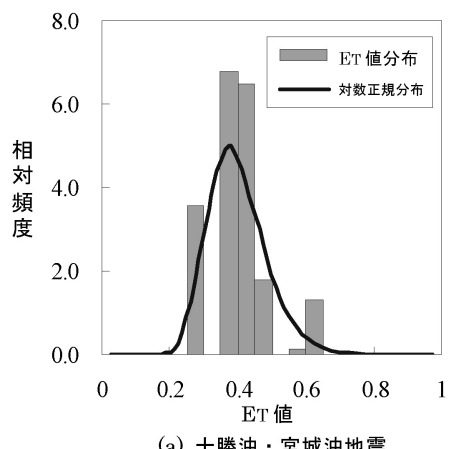

(a) 十勝沖・宮城沖地震

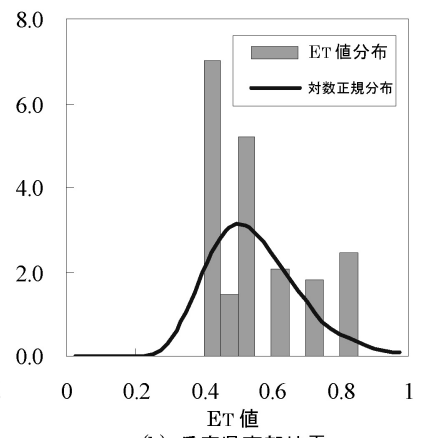

(b) 兵庫県南部地震

\section{（4）予測被害率}

図 $11 \mathrm{ET}$ 值の分布

予測被害率の算定にあたり、補強前は全データ 698 棟、補強後は 3. (2)で用いた 407 棟を対象とする。1968 年十勝沖・1978 年宮城県 沖地震・震度 Vレベル、および 1995 年兵庫県南部地震・震度VIレベ ルの地震動が起こったと仮定した場合の、中破以上の被害を受けると予 測される建築物の割合を図 12 に示寸。各建物の $I_{S}$ 値の梁間方向,桁行 方向及び最小值について示す。

震度 Vレベルの地震動に対して、補強により中破以上の被害建物 棟数は大幅に減少しほぼ 0 に近くなる。また、震度 VIレベルの地震 動に対しては、補強により中破以上の被害率は約 $1 / 4$ に低減する。 

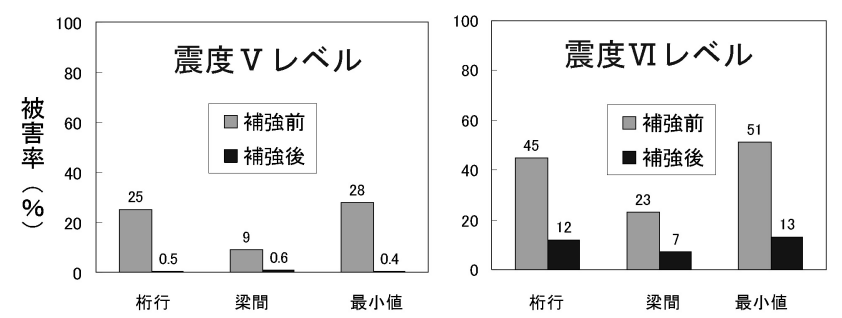

図 $12 \mathrm{RC}$ 造建築物の中破以上の予測被害率 $(\%)$

\section{（5）建物用途別による予測被害率}

震度VIレベルでの中破以上の被害率を建物用途別に図 13 に示寸。 補強前は 698 棟のうち、その他を除いた 610 棟、補強後は 370 棟を 対象とし、各建築物の最小 $I_{S}$ 值を用いて予測を行った。

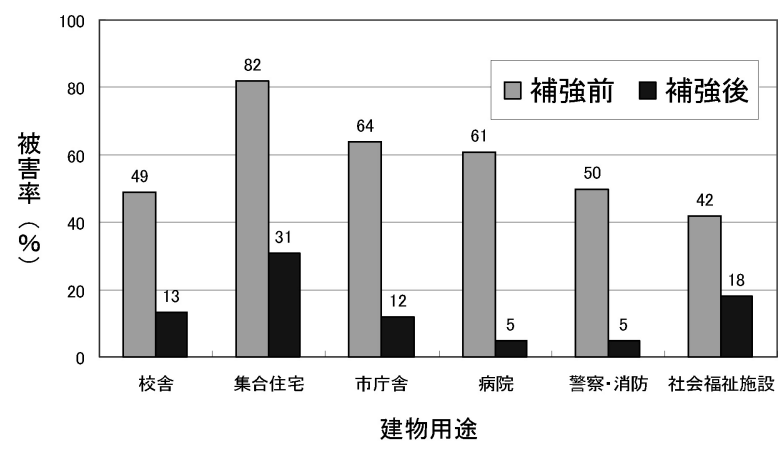

図 13 用途別の中破以上の予測被害率 (\%)(震度VIレベル)

図 13 より、集合住宅が他と比べて被害率が大きくなっている。こ れは集合住宅が他と比べて階数が多い（7層程度）ものが多く、階 数が多いほど $I_{S}$ 值が小さくなるためと考えられる。

（6）地域指標 $Z$ 別による予測被害率

北海道には地域指標 $Z$ が $0.8 、 0.9 、 1.0$ の 3 つの地域がある。補 強前は 698 棟のうち地域指標 $Z$ の記載のあった 686 棟、補強後は 385 棟を対象とする。地域指標 $Z$ 別(補強前の内訳は 0.8 が 69 棟、 0.9 が 501 棟、 1.0 が 116 棟 (図 14) ) の最小 $I_{S}$ 值相対頻度分布、平均 最小 $I_{S}$ 值および中破以上の被害率について検討した。以下にその結 果を示寸。

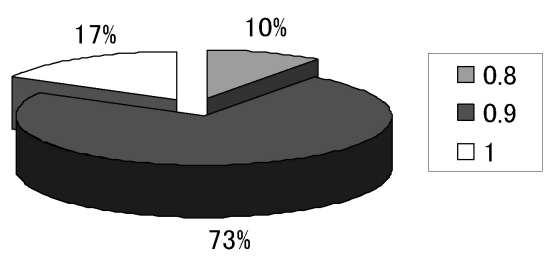

図 14 地域指標 $Z$ 毎の割合（補強前）

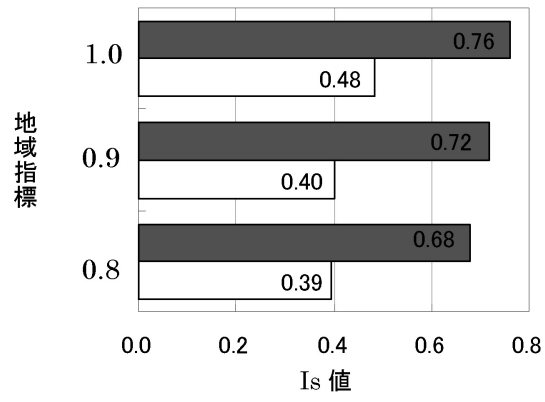

図 15 地域指標 $Z$ 毎の平均 $/ s$ 値
図 15、図 16 より地域指標 $Z$ が大きい地域ほど $I_{S}$ が大きく、従っ て被害率が小さくなる傾向があることが分かる。これは $Z$ が大きい 地域ほど、設計用地震力及び構造耐震判定指標 $I_{S O}$ 值が大きくなる ため、その結果 $I_{S}$ 值も大きくなるためである。
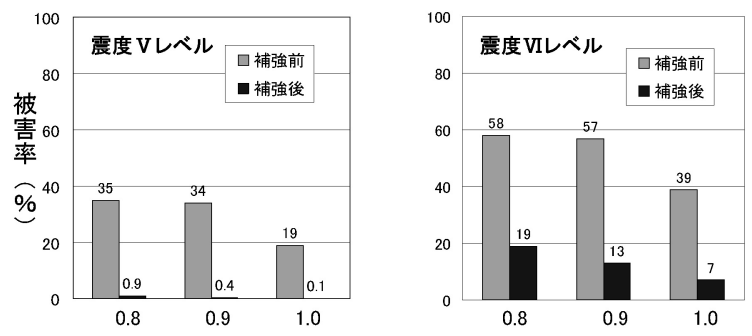

地域指標 $Z$

図 16 地域指標 $Z$ 毎の $\mathrm{RC}$ 造建築物の中破以上の予測被害率 $(\%)$

\section{（7）実測コンクリート強度を考慮した場合の建築物の被害予測}

耐震診断基隻 ${ }^{3)}$ による $I_{S}$ 值の算定では、大半の建築物においてコ ンクリート強度として設計図書に記載されている設計基準強度が用 いられている。ここでは、コンクリート強度の記載のあった 313 棟を対 象とし、実測コンクリート強度の影響を考慮するために文献 10)の方法に 倣い、構造耐震指標 $I_{S}$ 值の補正を行う。なお、コンクリート強度を 変えても勒性指標 $F$ 值は変化しないと仮定し、強度指標 $C$ のみによ り $I_{S}$ 值を補正し、実測コンクリート強度を考慮した構造耐震指標 $I_{S}^{\prime}$ を算定している。

$$
\begin{gathered}
I_{S}^{\prime}=I_{S} \times \beta \quad(9) \\
\text { ただし、 } \beta=\frac{\sigma_{B}}{F_{C}}\left(\sigma_{B} \leq F_{C}\right) 、 \beta=\sqrt{\frac{\sigma_{B}}{F_{C}}}\left(\sigma_{B}>F_{C}\right) \quad(10),(11) \\
\beta \text { :実測コンクリート強度による補正係数、 } \sigma_{B} \text { : 実測コンクリート強度 } \\
F_{C} \text { : 設計基準強度 }
\end{gathered}
$$

図 17 に設計基準強度を用いた場合、および実測コンクリート強度 を用いた場合の $I_{S}$ 值の頻度分布を示す。実測コンクリート強度を用 いた場合には、設計基準強度を用いた場合と比べて、頻度分布の極 値が減少するとともに、 $I_{S}$ 值が増加したことにより分布が全体的に 右側に移動している。

実測コンクリート強度を用いた場合の地震被害率は表 3 のように なり、設計基準強度を用いた場合に比べて震度 Vレベル、震度VIレ ベルともに約 $4 / 5$ に低下寸る。

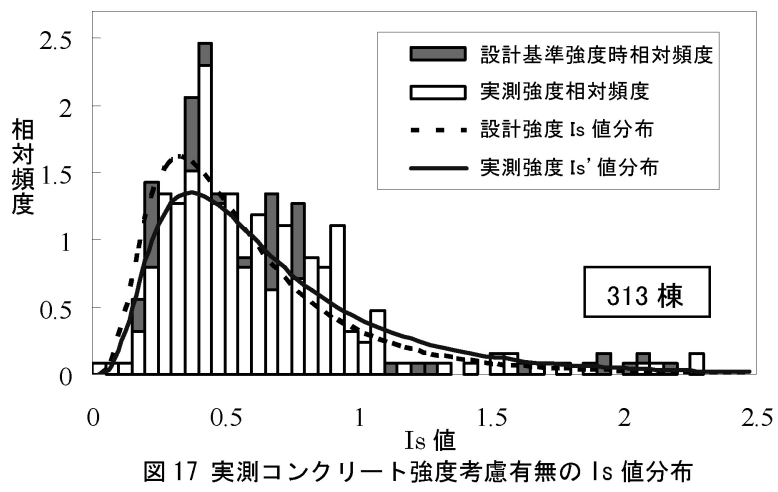

表 3 実測強度を考慮した場合の被害率の変化

\begin{tabular}{l|rr}
\hline & 設計基準強度 & 実測強度 \\
\hline 震度 Vレベル & $33 \%$ & $26 \%$ \\
震度VIレベル & $53 \%$ & $44 \%$ \\
\hline
\end{tabular}




\section{8. まとめ}

本研究では、耐震診断結果を用い、北海道の既存鉄筋コンクリート 造建築物の耐震性能や地震時の補強前後の耐震性能および地震被害 率を検討した。また、耐震診断の際に採取したコンクリートコア供試 体の圧縮試験より得られた推定強度と設計基準強度・䇋工年との関係、 及び実測コンクリート強度が地震被害率にどの程度影響を与えるか についても検討を行った。

以下に得られた知見を要約して示す。

（1） 1971 年以前に建設された建築物の $79 \%$ が $I_{S} \geq I_{S 0}$ を満たしておら ず、1971 年以降の建築物についても $I_{S} \geq I_{S 0}$ を満たしていないも のが多くみられる。

（2）耐震診断が実施された建築物のうち校舎が約6割を占めている。

（3）耐震補強方法としては、耐震壁の増設が最も多く、次に柱とそ れに接合されている壁との間を構造的に切り離すスリットが採 用されている。

（4）耐震補強（計画を含む）を行ったほとんどの建築物において、 基準化 $I_{S}$ 值、基準化 $C_{T U} \cdot S_{D}$ 值ともに 1 を上回るようになって いるが、基準化 $I_{S}$ 值、基準化 $C_{T U} \cdot S_{D}$ 值ともに 1 を下回るものが約 $10 \%$ 存在している。

（5）北海道の $\mathrm{RC}$ 造建築物の実測コンクリート推定強度を設計基準強 度で除した圧縮強度比の平均は 1.39 であり、設計基準強度を下 回るものは全体の約 $5 \%$ である。

（6）地震被害予測の結果、中破以上の被害を受ける建築物の割合は、 震度VIレベルで補強前 $51 \%$ 、補強後 $13 \%$ 、震度 Vレベルで補強 前 $28 \%$ 、補強後 $0.4 \%$ であり、耐震補強を行うことによって、中 破以上の被害率は、震度 $\mathrm{V}$ レベルの地震動に対しては大幅に減少 し、震度VIレベルの地震動に対しては約 $1 / 4$ に低減する。

（7）地域指標 $Z$ が大きい地域ほど $I_{S}$ 值が大きく、予測地震被害率が 小さくなる。
（8）実測コンクリート強度を考慮した予測地震被害率は、設計基準 強度を用いた場合に比べて震度 Vレベル、震度VIレベルともに約 4/5 に低下する。

\section{- 参考文献}

1）楊妹麗, 麻里哲広, 石山祐二, デ・グズマン フィリップ: 而震診断データ を用いた簡易 $\mathrm{RC}$ 造建物モデルの時刻歴解析に関する研究，構造工学論文集， Vo1. 51B, pp. 207-213, 2005. 3

2）楊妹麗，デ・グズマンフィリップ，麻里哲広，緑川光正，石山祐二 : 而震 診断結果を用いた北海道の既存 $\mathrm{RC}$ 造建物の而震性能に関寸る研究, 日本建築学 会技術報告集，第 22 号，pp. 205-210，2005. 12

3）日本建築防災協会:2001 年改訂版 既存鉄筋コンクリート建築物の而震診断 基準、2001

4）鈴木貴博、原健二、大網浩一、村上雅也：1987 年千葉県東方沖地震による被 災鉄筋コンクリート造建築物の耐震診断その 2 構造耐震指標值と被災程度、 日本建築学会学術講演梗概集 (九州)、pp. 869-870、1989 年 10 月

5) 周建東、広沢雅也、清水泰: 関東地方 $\mathrm{A}$ 県下における学校校舎の而震性能(そ の 4) コンクリート強度掞よび鉄筋種別、日本建築学会大会学術講演梗概集 (九 州)、pp. 619-620、1998 年 9 月

6）工藤仁、最知正芳、伊藤敬一、三橋博三、田中礼治、柴田明徳：東北地方の 既存 $R C$ 造建物の耐震診断および而震補強に関する調查研究、日本建築学会大会 学術講演梗概集 (東北)、pp. 297-298、2000 年 9 月

7）中埜良昭, 岡田恒男：信頼性理論による鉄筋コンクリート造建築物の而震安 全性に関する研究、日本建築学会構造系論文報告集第 406 号、pp. 37-43、1989 年 12 月

8）日本建築学会構造委員会：1995 年兵庫県南部地震鉄筋コンクリート造建築物 の被害調查報告書 第 II編学校建築、1997 年 3 月

9）齋藤陽子、澤木美穂、植松武是、麻里哲広、石山祐二：北海道における既 存鉄筋コンクリート造建築物の耐震性能 その 2 . 過去の地震被害デー夕を用い た被害率の推定、日本建築学会大会学術講演梗概集(北陸)、2002 年 8 月 10）高橋仁、広沢雅也、秋山友昭、田中恵司：鉄筋コンクリート造耐震壁の耐 震性能に関する総合研究 (その 11) せん断ひびわれ強度について、日本建築学会 大会学術講演梗概集 (東海)、pp. 1609-1610、1976 年 10 月

[2008 年 6 月 20 日原稿受理 2008 年 11 月 5 日採用決定］ 